\title{
Transgenic potato tubers as a source of phenolic compounds. Localization of anthocyanins in the peridermis $^{*}$
}

\author{
I. Kosieradzka ${ }^{1,4}$, W. Borucki ${ }^{2}$, I. Matysiak-Kata ${ }^{3}$, J. Szopa ${ }^{3}$ \\ and E. Sawosz' \\ Warsaw Agricultural University \\ 'Department of Animal Nutrition and Feed Science \\ Ciszewskiego 8, 02-786 Warsaw, Poland \\ 'Department of Botany, Faculty of Agriculture and Biology \\ Nowoursynowska 159 (02-776 Warsaw, Poland \\ 'Institute of Biochemistry and Molecular Biology, Wrockaw University \\ Przybyszewskiego 63. 51-148 Wroctaw, Poland
}

\begin{abstract}
The localization of phenolic compounds in tubers of transgenic potatoes overexpressing enzymes of the flavonoid synthesis pathway, i.e. chalcone synthase (CHS), chalcone isomerase (CHI) and dihydroflavonol dehydrogenase (DFR), was examined by fluorescence microscopy. The study revealed the presence of flavonoids (anthocyanins) in cell vacuoles, mainly in the peridermis. A relatively higher concentration of anthocyanin compounds was observed in the tissue of transgenic potato tubers, revealing the expression of chalcone synthase (CIIS). The increased content of flavonoids in transgenic potato tubers may affect their agrotechnical traits and may increase the nutritive value of the tubers.
\end{abstract}

KEY WORDS: transgenic potato, phenolics - anthocyanins, fluorescence microscopy

\section{INTRODUCTION}

Chalcone synthase (CHS), chalcone isomerase (CHI) and dihydroflavonol dehydrogenase (DFR) play key roles in the synthesis of flavonoids. Overexpression of these enzymes was obtained by the genetic modification of potato plants using petunia and barley genes. The studies of Stobiecki et al.

\footnotetext{
Supported by the State Committee for Scientific Research, Grant No. 3P06Z 00925

${ }^{4}$ Corresponding author: e-mail: kosieradzka@delta.sggw.waw.pl
} 
(2003) cmploying liquid chromalography/mass spectrometry revealed elevated concentrations of pelargonine and petunidine in transgenic potato tubers of the plants, indicating the overexpression of CHI and DFR.

A higher concentration of anthocyanins affects the nutritive value and dietetic propertics of potatoes, and also influences the agrotechnical properties of transgenic plants, i.e. increased resistance to pathogens, thermal stress and other phenomena (Kong et al., 2003). Phenolic compounds can be visualized under fluorescence microscopy (Ibrahim and Barron, 1989). In UV light, flavonoids located in cell vacuoles exhibit fluorescence and light absorption is related to the conductance of substrates and metabolites in the tissue of the plant (Havstecn, 2002).

The aim of the study was to determine, using microscopic methods, the localization and degree of concentration of cellular structures containing polyphenolic compounds in the tissue of transgenic plants overexpressing enzymes of the flavonoid synthesis pathway as well as eventually, to visualize the differences between the tissues of transgenic potato tubers of the 3 studied lines and of the traditional line of potatoes.

\section{MATERIAL AND METHODS}

The study material included the potato tubers of transgenic Solanum tuberosum L. cv Desiree. These tubers were compared with those of non-transgenic plants of the same variety. The following transgenic lines of potato were cultivated at the Institute of Biochemistry and Molecular Biology of Wroctaw University: CHS: overexpression of chalcone synthase deriving from barley; $\mathrm{CHI}$ : overexpression of chalcone isomerase coming from petunia; DFR: over-expression of dihydroflavonol dehydrogenase originating in the petunia. From about $4 \mathrm{~kg}$ batch of potatoes of each line, tubers of medium size and typical shape were selected for microscopic studies. "Free-hand" cross-sections of fresh potato tubers werc cut with a razor blade and placed in water or $20 \%$ glycerol and observed under a bright field or fluorescence microscopy. An Olympus Provis microscope was equipped with a L-MNU narrow-band filter cube and a D/F/TR triple-band filter cubc (Olympus) with excitation filter/barrier filter (nm) 360-370/>420 and $390-410,490-505,560-585 / 450-475,515-545$ and 605-680, respectively.

\section{RESULTS AND DISCUSSION}

"Frec-hand" sections of potato tuber peridermis of control and transformed plants were studied under bright field and fluorescence microscopy. The studies 


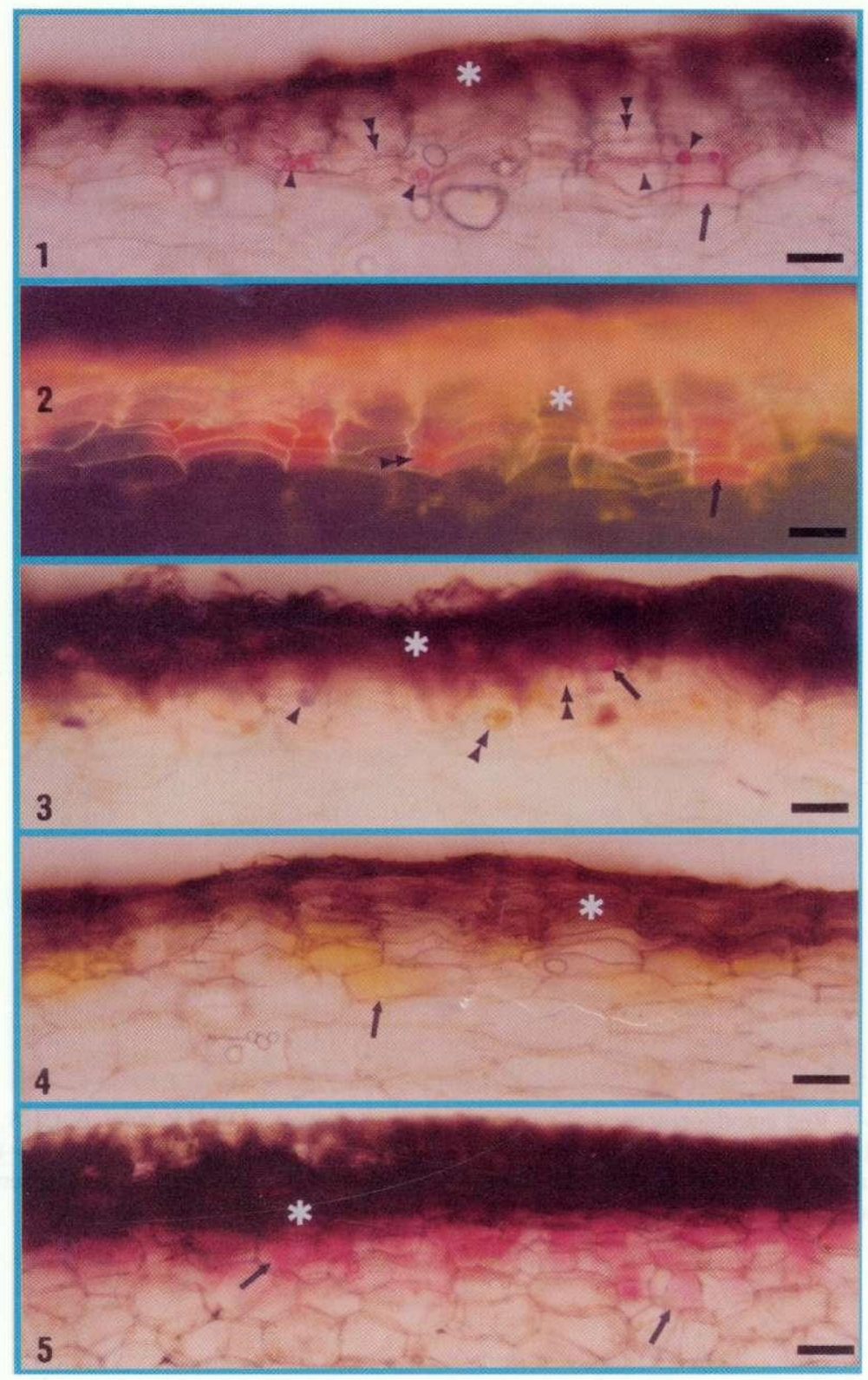

Figures 1-5. Light or fluorescence microscopy of "free hand"-sections of potato tuber peridermis (control plants). 1. Bright field microscopy reveals yellow (double arrowhead) or pink (arrowhead) spherical bodies within peridermal (asterisk) cells. Pink vacuolar content is marked (arrow). Bar $=50 \mu \mathrm{m}$. 2. Fluorescence microscopy (D/F/TR filter cube) of the section from Figure 2 reveals red fluorescence of vacuolar content (arrow) and spherical bodies (double arrowhead). Bar $=50 \mu \mathrm{m}$. 3. Sections treated with $1 \%$ ammonia. Notice blue (arrowhead) or pink (arrow) spherical bodies. Bar $=25 \mu \mathrm{m}$. 4. Vacuolar content is orange (arrow) under section treatment with $3 \%$ ammonia. Bar $=50 \mu \mathrm{m}$. 5. Sections treated with $1 \%$ acetic acid. Vacuolar content is pink (arrows). Bar $=50 \mu \mathrm{m}$ 

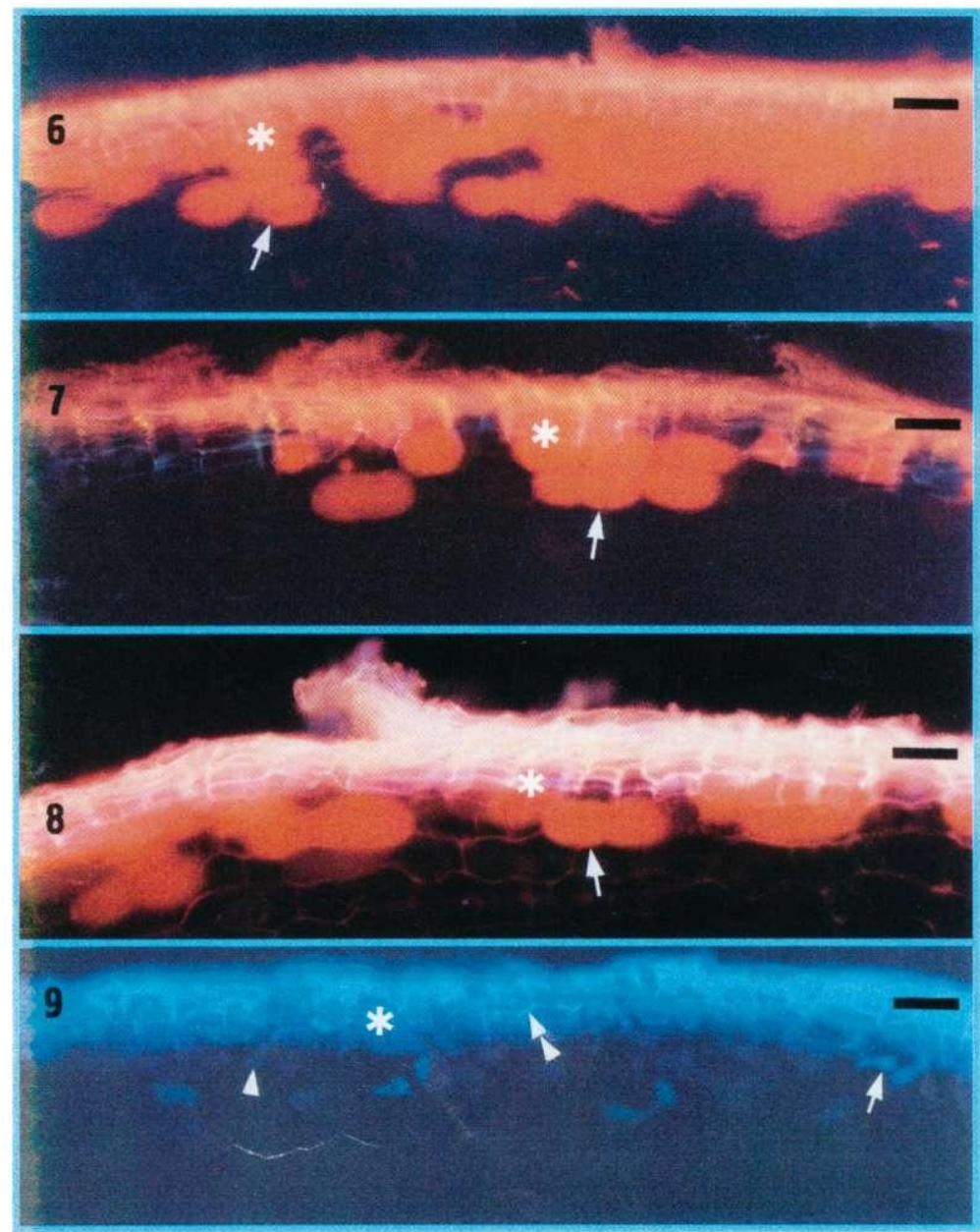

Figures 6-9. Red autofluorescence of vacuolar content (arrows) - D/F/TR cube. 6. CHS. 7. CHI. 8. DFR plant sections. Bars $=50 \mu \mathrm{m}$. 9. Blue autofluorescence of corky layer (especially cell walls - double arrowhead) and blue or violet autofluorescence of vacuolar content of peridermal cells (arrow and arrowhead respectively). Control plants - U-MNU cube. Bar $=100 \mu \mathrm{m}$ 
revealed that one to three peridermal cell layers contained yellow or pink spherical bodies (Figure 1). Some of the largest pink bodies became blue under treatment with $1 \%$ ammonia (Figure 3). On the other hand, $3 \%$ ammonia treatment resulted in an orange vacuolar content (Figure 4). The bright pink vacuolar content (Figure 1) became intensively pink (Figure 5) under 1\% acetic acid treatment. The bodies and vacuoles therefore contain phenolics, including anthocyanidins. UV irradiation (U-MNU filter cube) resulted in blue autofluorescence of corky cell walls and blue or violet autofluorescence of the vacuolar content of the rest of the peridermal cells. Violet autofluorescence of the vacuolar content indicated the presence of anthocyanidins. The intensity of vacuolar content autofluorescence was, however, rather weak (Figure 9). Much more intensive red autofluorescence of anthocyanidins contained in vacuoles was achieved under violet, blue and green irradiation (D/F/TR filter cube - Figures 2, 6, 7, and 8). The effectiveness of a triple band pass filter (Zeiss, Chroma Technology) between blue and green fluorescence of (un)lignified cell walls was demonstrated by Rudall and Caddick (1994). Using "free hand" sections permitted only crude comparisons between the autofluorescence of controls (Figure 2) and transformed plants (Figures 68). Nevertheless, it appears that CHS plants often possessed 3-4 peridermal cell layers that gave intensive red autofluorescence of their vacuolar contents (Figure 6), whereas control (Figure 2), CHI and DFR plants had only 2-3 layers (Figures 7 and 8). Increased concentrations of cell structures containing flavonoids were not found in tuber parenchyma (below the peridermis) of the transgenic potatoes.

\section{CONCLUSIONS}

Microscopic examination of the tissues of transgenic potato tubers overexpressing the enzymes CHS, CIII and DFR showed the presence of phenolics in the vacuoles of cells located in the peridermal cell layer. Flavonoids were found in the periderm of tubers of both transgenic and non-transgenic potatoes. Thus, genetic modification did not influence the localization of polyphenolics in the tubers. A relatively higher concentration of phenolic compounds was found in the tissue of transgenic potato tubers. Due to the localization of cellular structures (vacuoles) containing phenolic compounds in the peridermis of the tubers, the inclusion of such potatoes into the diet may be beneficial for the consumer only under the condition that the tubers are consumed as a whole, that is, without the removal of peridermis. 


\section{REFERENCES}

Ilavsteen B.H., 2002. The biochemistry and medical significance of the flavonoids. Pharmacol. Ther. 96, 67-202

Ibrahim R.K., Barron D., 1989. Phenylopropanoids. In: P.M. Day, J.B. Harbome (Editors). Methods in Plant Biochemistry, Vol. I. Plant Phenolics. New York, Academic Press, pp. 197-235

Kong J., Chia L., Goh N., Chia T., Brouillard R., 2003, Analysis and biological activities of anthocyanins. Phytochemistry 64, 923-933

Rudall P.J., Caddick L.R., 1994. Investigations of the presence of phenolic compounds in monocotyledonous cell walls, using fluorescence microscopy. Ann. Bot. 74, 483-491

Stobiecki M., Matysiak-Kata I., Frański R., Skała J., Szopa J., 2003. Monitoring changes in anthocyanin and steroid alkaloid glycoside content in lines of transgenic potato plants using liquid chromatography/mass spectrometry. Phytochemistry 62, 959-969

\section{STRESZCZENIE}

Bulwy transgenicznych ziemniakow jako źrodlo zwiazków fenolowych. Lokalizacja antocyjanów w perydermic

Lokalizacje związków fenolowych w bulwach transgenicznych ziemniaków wykazujących nadekspresję enzymów szlaku syntezy flawonoidów izomerazy chalkonu (CHI), syntazy chalkonu (CHS) i dehydrogenazy dihydroflawonolu (DFR) badano metodą mikroskopii fluorescencyjnej. Wykazano obecnosć flavonoidów (antocyjanów) w wakuolach komórek zlokalizowanych głównie w warstwie perydermy. Stosunkowo większą zawartość związków fenolowych stwierdzono w tkance bulw ziemniaków transgenicznych wykazujących ekspresję syntazy chalkonu (CHS). Zwiçkszona zawartość flavonoidów w bulwach transgenicznych ziemniaków może wpływać na cechy agrotechniczne, ale przede wszystkim podnosić wartość odżywczą bulw. 